\title{
Investigation of Activity, Participation and Quality of Life in Elderly Living in Ankara and Antalya Provinces
}

\section{Ankara ve Antalya illerinde Yaşayan Yaşlılarda Aktivite, Katılım ve Yaşam Kalitesinin İncelenmesi}

\author{
(D) Hasan Atacan TONAK1, id Özgün KAYA KARA1, id Sedef ŞAHIN²
}

${ }^{1}$ Akdeniz University Faculty of Health Sciences, Department of Physiotherapy and Rehabilitation, Antalya, Turkey

${ }_{2}^{2}$ Hacettepe University Faculty of Health Sciences, Department of Occupational Therapy, Ankara, Turkey

\begin{abstract}
Objective: This aim of this study was to investigate the relationship between activity, participation and quality of life in the elderly living at home.

Methods: This study was applied to 120 elderly people (60 females, mean age: $71.4 \pm 5.3$ years; 60 males, mean age: $70.8 \pm 4.7$ years, ranged between $65-83$ years) aged 65 years and older and living at their home in Ankara and Antalya. The community participation levels were assessed with World Health Organisation Disability Assessment Schedule, Second Version (WHO-DAS-II). Canadian Occupational Performance Measure (COPM) was used to evaluate the activity performance of participants. The elderly's quality of life levels were assessed with Health Survey Questionnaire Short Form36 (SF-36).
\end{abstract}

Results: The important daily living activities of participants in which they had problems were: Cooking $(n=52)$, shopping $(n=48)$, having a shower $(\mathrm{n}=38)$ and praying (salaat) $(\mathrm{n}=37)$. According to the results of WHO-DAS-II, COPM and SF-36, there were no statistical differences between gender groups $(p>0.05)$. There was a moderate significant negative correlation between the sub-scores of COPM and total score of WHO-DAS-II $(\mathrm{p}<0.05)$. Also, There was a weak-strong significant negative correlation between all subparameters of SF-36 and WHO-DAS-II total score and community participation sub-parameter $(\mathrm{p}<0.05)$.

Conclusion: Our study showed that the community participation of elderly people living in the home increased with the increase in

\section{ÖZ}

Amaç: Çalışmamızın amacı; evde yaşayan yaşlıların aktivite, katılım ve yaşam kalitesi düzeyleri arasındaki ilişkiyi incelemektir.

Yöntemler: Çalışmamız Ankara ve Antalya illerinde, kendi evlerinde yaşayan 65 yaş ve üstündeki 120 yaşlı bireyde (60 kadın, ortalama

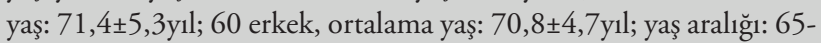
83 yıl) gerçekleştirildi. Toplumsal katılım düzeyleri, Dünya Sağlık Örgütü tarafından geliştirilen Yetiyitimi Değerlendirme ÇizelgesiII (WHO-DAS-II) ile değerlendirildi. Katılımcıların aktivite performanslarını değerlendirmek için Kanada Aktivite Performans Ölçümü (KAPÖ) kullanıldı. Yaşlıların yaşam kalitesi düzeyleri Kısa Form-36 (KF-36) Sağlık Taraması Anketiyle değerlendirildi.

Bulgular: Katılımcıların günlük yaşamlarında performans problemi yaşadıkları önemli aktiviteler; yemek yapma $(\mathrm{n}=52)$, alış-veriş yapma $(\mathrm{n}=48)$, duş alma $(\mathrm{n}=38)$ ve namaz kılma $(\mathrm{n}=37)$ aktiviteleriydi. WHO-DAS-II, KAPÖ ve KF-36 değerlendirme ölçeklerinin sonuçlarında cinsiyetler arasında istatistiksel olarak anlamlı bir fark tespit edilmedi $(p>0,05)$. KAPÖ'nün alt puanları ile WHO-DASII'nin toplam puanı arasında istatistiksel olarak orta derece negatif yönde anlamlı bir ilişki bulundu $(\mathrm{p}<0,05)$. KF-36 ile WHO-DASII arasındaki ilişkiyi incelediğimiz zaman ise KF-36'nın bütün alt parametreleriyle WHO-DAS-II'nin toplumsal katılım alanı ve toplam puanı arasında istatistiksel olarak zayıf-güçlü derece negatif yönde anlamlı bir ilişki olduğu tespit edildi $(\mathrm{p}<0,05)$.

Sonuç: Çalışmamızda, evde yaşayan yaşlı bireylerin aktivite performanslarının artmasıyla toplumsal katılımlarının arttığı,
Address for Correspondence: Hasan Atacan TONAK, Akdeniz University Faculty of Health Sciences, Department of Physiotherapy and Rehabilitation, Antalya, Turkey

E-mail: atacantonak@akdeniz.edu.tr ORCID ID: orcid.org/0000-0002-3545-936X
Received: 24.05 .2019

Accepted: 15.10 .2019

Cite this article as: Tonak HA, Kaya Kara Ö, Şahin S. Investigation of Activity, Participation and Quality of Life in Elderly Living in Ankara and Antalya Provinces. Bezmialem Science 2020;8(3):238-45. 
their activity performance, and their quality of life increased with their increased community participation. Future studies should be designed to investigate the effects of environmental factors and different living conditions on activity, participation and quality of life of elderly individuals.

Keywords: Elderly, participation, activity, quality of life toplumsal katılımlarının artmasıyla da yaşam kalitelerinin arttığı yönünde sonuçlar elde edilmiştir. Gelecekteki çalışmalar çevresel faktörlerin ve farklı yaşam koşullarının geriatrik bireylerin aktivite, katılım ve yaşam kalitesi üzerine etkilerini araştırmak amacıyla tasarlanmalıdır.

Anahtar Sözcükler: Yaşlı, katılım, aktivite, yaşam kalitesi

\section{Introduction}

Aging is an inevitable part of life cycle and it is a normal process which has chronological, psychological and social dimensions, is characterized by progressive physiological changes, and is associated with increased rate of acute and chronic diseases $(1,2)$. Aging is a deficiency condition accompanied by different diseases, in which physiological, morphological and pathological changes occur, and physical, mental and spiritual abilities in the individual change negatively (3). One of the impenetrable results of aging is the decrease in the biological capacity of the person. With aging, some changes occur in all tissues, organs and system functions. Due to the changes in the muscular and skeletal systems, respiratory system, nervous system, cardiovascular system and metabolism in old age, geriatric individuals are restricted from their activities in their daily lives or they have difficulty in performing these activities $(4,5)$.

Old age is the last stage in the development of people. In this period, all features of aging become visible (6). In old age, there is a decrease in participation in activity, a decrease in positive emotions, a decrease in quality of life and a limited community participation (7). Although it is generally accepted that the participation of elderly individuals in community life is decreasing, their needs for community participation are similar to those of middle-aged individuals. In this context, the decrease in community participation, which is one of the consequences of old age, is a result of the decrease in the interaction of other individuals in the society with older individuals (8).

One of the conditions of being healthy is to participate in an activity and be able to do it properly and correctly. It has been concluded that participation in activities supports people to feel healthy and better (6). Very few elderly people who live at home and do not participate in regular activities feel healthy. Participating in daily life activities or entering a social creation process makes individuals feel healthy (9). Activity performance and community participation of older adults are particularly important. Because, with aging, the participation of adults in many activities and tasks decreases with negatively affected health (8). Community participation and activity performance is important for the quality of life in general among elderly individuals (10).

Old age, which is an inevitable phase, can be turned into a quality and fun time. One of the most fundamental rights of people is to take equal advantage of all the opportunities offered by social life (11). Like every person, older individuals should be equal and participatory in all areas of social life. Being in life makes one feel important and develop, socioculturally (10). Participation in meaningful and purposeful activities ensures the continuity of health and quality of life. Participation in social and physical activity reduces the risk of mortality, improves quality of life and increases survival rate (12). When the literature is examined, there are studies examining the activity preferences, community participation levels and life satisfaction of the elderly. It is seen that these studies are generally done in nursing homes. At the same time, it has been observed that these studies have not examined community participation, activity performance and quality of life levels together $(6,13,14)$.

Inadequacy and restrictions may occur in old age. Due to this limitation and inadequacy, there is a general acceptance that the participation of elderly individuals in community life, their activity performance and quality of life have been impaired (13). From this point of view, examining the community participation, quality of life and activity performances of elderly people living at home will be important in terms of learning their roles in social life. For this reason, the purpose of our study was to examine the community participation, activity performance and quality of life levels of the elderly living at home and to reveal the relationship between them.

\section{Methods}

This study was approved by the Clinical Research Ethics Committee of Akdeniz University Faculty of Medicine (70904504/85, decision no: 178). All elderly people included in the study were given detailed information about the study and their written consent was obtained before the evaluation. Our study was carried out cross-sectionally in Ankara and Antalya between February 2019 and May 2019, in individuals aged 65 and over who lived in their own homes.

Criteria for inclusion in the study were; (1) being 65 years old or older, (2) living in a home, (3) functionality not affected by a disease or disability diagnosed by the doctor, (4) having 24 points or more points in the Standardized Mini Mental Test. Exclusion criteria were; (1) not agreeing to participate in the study, (2) having undergone surgery in the past 6 months, (3) having a diagnosis of chronic disease such as neurological, rheumatological, psychiatric, orthopedic disorders and cancer, and (4) having an advanced communication problem due to mental and cognitive problems.

Community participation levels of elderly individuals living in the home environment were evaluated using the World Health Organisation Disability Assessment Schedule, Second Version 
(WHO-DAS-II). The Turkish validity and reliability study of WHO-DAS-II was done by Uluğ et al. (15). In this evaluation schedule, how much difficulty the individual has had during the last month is determined and it is completed in 20 minutes. In scoring, field scores and total score are evaluated over 100 . The low value of each field and the total score indicates that the participation is higher (16).

Canadian Occupational Performance Measure (COPM) was used to evaluate the activity performances of the participants from their own perspective. The Turkish validity and reliability study of COPM was performed by Torpil et al. (17). COPM is an interview that helps identify problems in activity performance. COPM is a measurement that evaluates the activity performance in self-care, productivity and leisure time and how satisfied they are with this perspective from one's own perspective. COPM focuses on the activities that are wanted or needed by the individual and in which the individual has a performance problem. Firstly, the importance of each activity, as perceived by the individual, is evaluated on a 10-point scale. In the next step, the individual is asked to choose the activities that are most important to him/her and score the performance and satisfaction levels separately for these activities. The performance and satisfaction scores obtained are totaled separately and the total performance and satisfaction scores are calculated by dividing the performance and satisfaction scores with the number of activities which are stated important by individual (18).

The quality of life levels of the elderly individuals who participated in the study were evaluated with the Health Survey Questionnaire Short Form-36 (SF-36). SF-36, which was launched in 1992 and could evaluate both positive and negative aspects of health status, could be completed in five minutes. The scale includes 36 items and they provide evaluation of 8 dimensions; physical functionality, social functionality, pain, general health, energy/vitality, physical role weakness, emotional role weakness and mental health. The last 4 weeks are taken into consideration when evaluating with SF-36. The scale does not only give a single total score, it gives different results for each subscale. Results evaluate health between 0 and 100 points, and 0 indicates poor health, while 100 indicates a good health $(19,20)$. The Turkish reliability and validity study of the SF-36 was conducted by Koçyiğit et al. (21).

\section{Statistical Analysis}

The data obtained in our study were analyzed statistically using Windows based SPSS (IBM SPSS Statistics, Version 23.0, Armonk, NY, USA) package program. The sample group was calculated using GPower V.3.1.7 (University of Kiel, Kiel, Germany). The number of individuals to be included in the study was determined to be 78 according to $80 \%$ power and 95\% confidence interval (13). Analytical (Kolmogorov-Smirnov I Shapiro-Wilks test) and visual (Histogram and probability graphs) methods were used to test the normal distribution of the data. Descriptive statistics were given as mean \pm standard deviation $(\bar{x} \pm S D)$ and \%. In order to measure the statistical significance of the difference between male and female elderly people, t-test was used for independent groups in normally distributed data groups. Sperman Correlation Analysis was used to analyze the relationship between community participation, activity performance and quality of life levels. In the evaluation of the relationship, the relationship was accepted as weak if the correlation coefficient was $0-0.24$, moderate if it was 0.25 0.49 , strong if it was $0.50-0.74$, very strong if it was 0.75 1.00 (22). Multiple linear regression analysis was performed between the community participation and the model created with independent variables that were significant. In our study, statistical significance level was accepted as $\mathrm{p}<0.05$.

\section{Results}

In our study, 60 (50\%) females aged between 65 and 83, with a mean age of $71.4 \pm 5.3$ years, and $60(50 \%)$ males with a mean age of $70.8 \pm 4.7$ years (a total of 120 elderly individuals) were included. Forty seven $(39.17 \%)$ of the participants were primary school graduates and $11(9.17 \%)$ were university graduates. Ninety seven $(80.83 \%)$ of the elderly individuals who participated in the study were retired. The right extremities of 116 (96.7\%) participants were dominant. While 101 (84.17\%) of the participants stated that they lived with their spouse, only $7(5.83 \%)$ of the participants stated that they lived alone. Other descriptive information of the elderly individuals included in the study is given in Table 1 .

When the important activities that the participants experienced performance problems in their daily lives were examined, it was found that taking a shower $(\mathrm{n}=38)$ in the self care area, cooking

Table 1. Descriptive features of the elderly

\begin{tabular}{|c|c|c|}
\hline Variables & $n=120$ & $\%$ \\
\hline \multicolumn{3}{|l|}{ Gender } \\
\hline Female & 60 & 50 \\
\hline Male & 60 & 50 \\
\hline \multicolumn{3}{|l|}{ Education level } \\
\hline Illiterate & 8 & 6.67 \\
\hline Literate & 19 & 15.83 \\
\hline Primary school & 47 & 39.17 \\
\hline Secondary school & 33 & 27.5 \\
\hline University & 11 & 9.17 \\
\hline Postgraduate & 2 & 1.67 \\
\hline \multicolumn{3}{|l|}{ Place of residence } \\
\hline Apartment & 109 & 90.83 \\
\hline Separate & 11 & 9.17 \\
\hline \multicolumn{3}{|l|}{ Home layout } \\
\hline Lone & 7 & 5.83 \\
\hline Leaving with partner & 101 & 84.17 \\
\hline $\begin{array}{l}\text { Living with relatives (child, } \\
\text { brother, sister nephew, etc.) }\end{array}$ & 12 & 10 \\
\hline \multicolumn{3}{|l|}{ Income level } \\
\hline$<2000 \mathrm{TL}$ & 78 & 65 \\
\hline$>2000 \mathrm{TL}$ & 42 & 35 \\
\hline
\end{tabular}


$(\mathrm{n}=52)$ in the productivity area, and praying $(\mathrm{n}=37)$ in the leisure activities area were at the forefront (Table 2).

When all sub-parameters and total score of WHO-DAS-II were compared by gender, no significant difference was found between male and female participants $(\mathrm{p}>0.05)$. Total performance, total

Table 2. Activities that participants have performance problems according to the canadian occupational performance measure

\begin{tabular}{|c|c|c|}
\hline COPM & $n$ & $\%$ \\
\hline \multicolumn{3}{|l|}{ Self care area } \\
\hline Having a shower & 38 & 31.67 \\
\hline Praying & 37 & 30.83 \\
\hline Shaving & 22 & 18.33 \\
\hline Walking & 21 & 17.50 \\
\hline Getting dressed & 19 & 15.83 \\
\hline Cutting nail & 16 & 13.33 \\
\hline Performing wudu & 14 & 11.67 \\
\hline \multicolumn{3}{|l|}{ Productivity area } \\
\hline Cooking & 52 & 43.44 \\
\hline Shopping & 48 & 40.00 \\
\hline Cleaning & 33 & 27.50 \\
\hline Washing the clothes & 31 & 25.83 \\
\hline Ironing & 30 & 25.00 \\
\hline Using mobile phones & 28 & 23.33 \\
\hline Using computer & 20 & 16.66 \\
\hline Going to work & 13 & 10.83 \\
\hline \multicolumn{3}{|l|}{ Leisure activities area } \\
\hline Hand making & 25 & 20.83 \\
\hline Visiting relatives & 21 & 17.50 \\
\hline Visiting friends & 16 & 13.33 \\
\hline Driving a car & 14 & 11.67 \\
\hline Reading books & 8 & 11.01 \\
\hline Watching TV & $\begin{array}{l}0 \\
7\end{array}$ & 5.81 \\
\hline $\begin{array}{l}\text { Playing backgammon/ } \\
\text { playing cards }\end{array}$ & 3 & $\begin{array}{l}5.83 \\
2.50\end{array}$ \\
\hline
\end{tabular}

satisfaction, and total score in COPM were found to be similar in female participants compared to male participants ( $p>0.05)$. There was no statistically significant difference between subparameters of SF-36 in terms of gender $(p>0.05)$.

When we examined the relationship between community participation and activity performance, a statistically moderately negative correlation was found between total performance, total satisfaction and total scores of the COPM and the total score of WHO-DAS-II $(\mathrm{p}<0.05)$ (Table 3$)$. When we examined the relationship between community participation and quality of life, a statistically weak negative correlation was found between SF-36's pain parameter and WHO-DAS-II's community participation area and total score; a statistically moderately negative correlation between SF-36's physical functionality, social functionality, general health and mental health parameters, and WHO-DAS-II's community participation area and total score; and a statistically strong negative correlation was found between SF-36's energy/vitality, physical role weakness and emotional role weakness and WHO-DAS-II's community participation area and total score $(\mathrm{p}<0.05)$ (Table 4).

As a result of the multiple linear regression analysis performed with the total score of WHO-DAS-II and with the model created with COPM's total performance, total satisfaction and total score, and SF-36's physical functionality, social functionality, pain, general health, energy/vitality, physical role weakness, emotional role weakness, and mental health sub-parameters, all of which were found significant in univariate analysis; COPM's all scores and SF-36's sub-parameters were found to have an independent effect on community participation $(\mathrm{p}<0.05)$. Accordingly, a negative correlation was found between all scores of COPM and all sub-parameters of SF-36 and the total score of WHO-DAS-II $(\mathrm{p}<0.05)$ (Table 5).

\section{Discussion}

In our study, which was planned to examine the community participation, activity performance and quality of life levels of elderly people living at home and to reveal the relationship between them; it was shown that community participation was increased with the increase in activity performance and

\section{Table 3. Examining the Relationship Between WHO-DAS-II Results and COPM Scores}

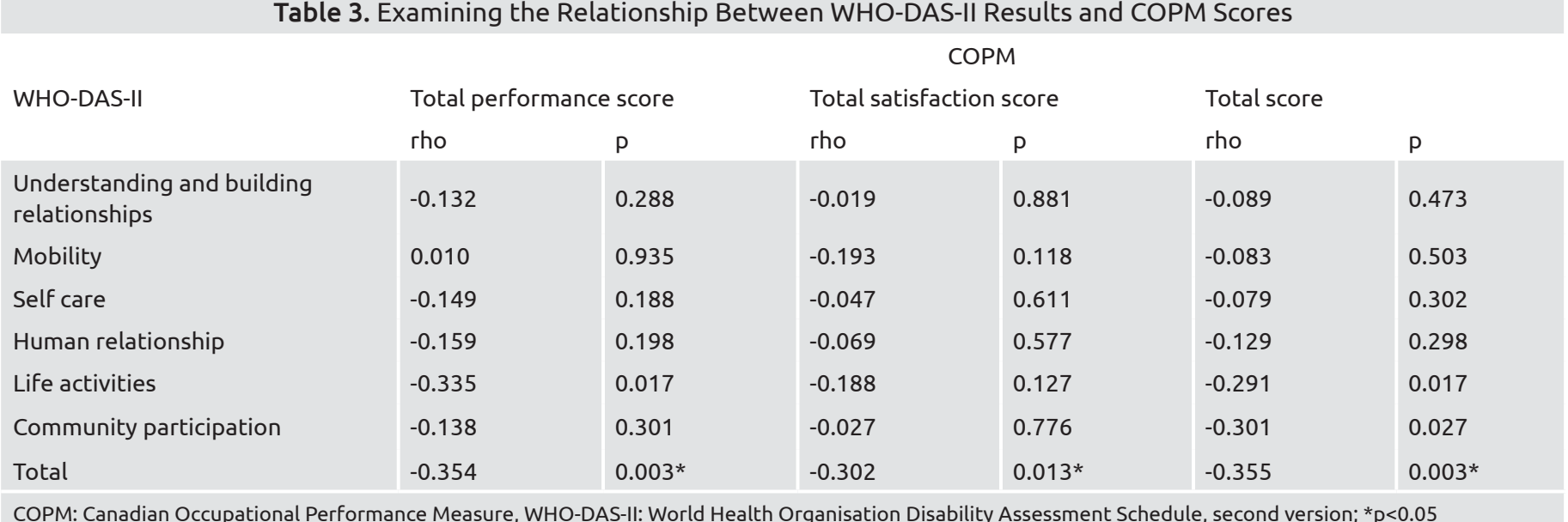

COPM: Canadian Occupational Performance Measure, WHO-DAS-II: World Health Organisation Disability Assessment Schedule, second version; * $p<0.05$ 


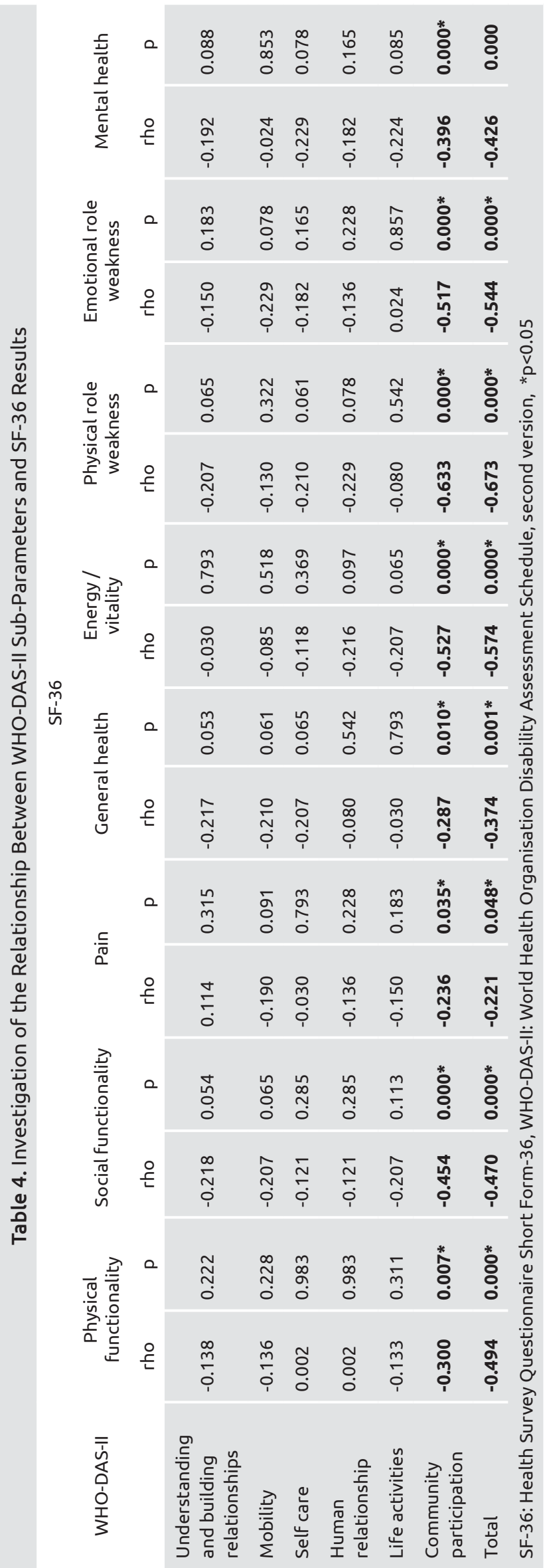

that quality of life was increased with increasing community participation. Evaluation of all the community participation, activity performance and quality of life of elderly people living at home and showing the interactions between them were the main differences that distinguished our study from other studies.

The concept of community participation is multidimensional. It is important what individuals do, their personal preferences, interests, how and where they do it, how much they have fun and are satisfied (11). Community participation levels increase by ensuring the participation of elderly individuals in various activity groups in basic and auxiliary daily life activities, ensuring that the elderly are productive and socialized and that the sense of isolation in them decreases (6). Person, activity and environmental factors are related to each other and these factors should be taken into consideration while examining community participation. As for all people, community participation is very important for the elderly who live at home. In studies on community participation, participation has been shown to be effective on quality of life and general well-being (11,23-25). Decrease in community participation does not only adversely affect physical health, it also affects the person emotionally and psychologically (26).

It has been shown that the activity preference and participation in the elderly individuals are generally associated with the socioeconomic status and health level, therefore, regardless of the activity performance area, the quality of life and community participation of the elderly who continue their performance and participation in the activities they choose are higher (24). Göktaş et al. (6) stated that the most affected activity performances

\begin{tabular}{|c|c|c|c|}
\hline & $\begin{array}{l}\text { Unstandardized } \\
\text { beta }\end{array}$ & $\begin{array}{l}\text { Standardized } \\
\text { beta }\end{array}$ & $\mathrm{P}$ \\
\hline Constant & 63.572 & & $0.00 *$ \\
\hline $\begin{array}{l}\text { COPM Total } \\
\text { performance score }\end{array}$ & -0.956 & -0.192 & $0.00 *$ \\
\hline $\begin{array}{l}\text { COPM Total } \\
\text { satisfaction score }\end{array}$ & -0.873 & -0.186 & $0.00 *$ \\
\hline COPM Total score & -0.673 & -0.094 & $0.00 *$ \\
\hline $\begin{array}{l}\text { SF-36 Physical } \\
\text { functionality }\end{array}$ & -0.163 & -0.332 & $0.00 *$ \\
\hline $\begin{array}{l}\text { SF-36 Social } \\
\text { functionality }\end{array}$ & -0.094 & -0.333 & $0.00 *$ \\
\hline SF-36 Pain & -2.063 & -0.137 & $0.02 *$ \\
\hline SF-36 General health & -0.483 & -0.082 & $0.00 *$ \\
\hline SF-36 Energy/vitality & -3.092 & -0.135 & $0.00 *$ \\
\hline $\begin{array}{l}\text { SF-36 Physical role } \\
\text { weakness }\end{array}$ & -4.652 & -0.127 & 0.00 * \\
\hline $\begin{array}{l}\text { SF-36 Emotional role } \\
\text { weakness }\end{array}$ & -2.193 & -0.173 & $0.00 *$ \\
\hline SF-36 Mental health & -1.984 & -0.393 & $0.00 *$ \\
\hline
\end{tabular}

COPM: Canadian Occupational Performance Measure, SF-36: Health Survey Questionnaire Short Form-36, *p<0.05 
among the geriatric individuals were in activities including cleaning, praying, visiting and shopping, respectively (6). In a study conducted on the elderly in the nursing home, it was found that the activity of taking a bath was expressed as the most common problem and praying as the second most common problem (27). In parallel with these two studies, the most difficult and problematic activities of the elderly were cooking $(n=52)$, cleaning $(n=33)$, shopping $(n=48)$, taking a shower $(n=38)$, and praying (salaat) $(\mathrm{n}=37)$ in our study. While performing these activities, it has been shown in the literature that muscle strength and endurance are needed and there is a decrease in lower and upper extremity muscle strength and endurance along with aging $(28,29)$. Göktaş et al. (6) has stated that the reasons for having problem while performing activities such as cooking, shopping, praying and cleansing are; less movement due to the decrease in muscle strength and endurance; not having people living with them and supporting them; and getting not enough support (6). In our current study, we thought that the reason for the presence of activities such as ironing ( $n=30)$, washing clothes $(n=31)$, shopping $(n=48)$ and driving $(n=14)$, which we identified as different activities that the participants had problems with, was that geriatric individuals living at home had to fulfill their responsibilities themselves. At the same time, in our study, it was seen that the most important problem of elderly people living in their homes was taking shower $(n=38)$. We think that this is due to the fear and danger of falling because of the difficulty of taking the necessary support during the shower from the family members or their relatives, and due to the wet shower area which is considered not a safe area.

When we examined the relationship between the community participation and activity performances of the elderly individuals included in the study, a statistically significant relationship was found between the total performance, total satisfaction and total score of the COPM and the total score of the WHO-DAS-II. Pino et al. (26) stated in their studies in 2014 that participation in the activity and performance in the activity increased the level of community participation of the person. In studies where it has been shown that appropriate physical activity and social activity in older individuals have increased their community participation, it has also been shown that participation in activity also poses a low risk for dementia by preventing cognitive decline $(30,31)$. Salar et al. (23) determined in their study on 55 elderly individuals living in their homes in 2016 that their participation in activities that were important and meaningful for them and their environment affected the participation levels of elderly individuals. Similar to these studies, it was found that the level of community participation was positively affected by the increase in activity performance in our study. In a study conducted in 2010 that supported our current work with this aspect, Kayıhan et al. (32) found that there was a relationship between activity performance and environmentally compatible behavior, and that the level of participation of individuals increased with the increase in activity performance and that they lived more socially. Likewise, there are also studies showing that as the general well-being of individuals increases, their activity performance increases and thus their community participation levels increase $(11,24,26,33)$.
In our current study where we examined the relationship between community participation and quality of life; there was a statistically significant relationship between community participation field and the total score of WHO-DAS-II and the parameters of SF36 including physical functionality, social functionality, pain, general health, energy/vitality, physical role weakness, emotional role weakness and mental health. Meaningful activities and participation in the elderly are important for the continuity of quality of life (23). Human beings continue their health and quality of life as long as they continue to participate in activities that have meaning and purpose for themselves. Participation in daily life activities and free time activities has been stated to be the most important parameter of being a part of the society as well as maintaining the personal well-being (26). In this way, it was found that the quality of life of elderly individuals increased (26). In a study where community participation was evaluated with WHO-DAS-II and quality of life with SF-36, it was shown that the level of quality of life was positively affected by the increase in community participation (11). In a study examining the functional status and quality of life levels of a total of 164 elderly individuals; as the Tinetti score increased, an increase in the physical functionality and mental health scores of the SF36 quality of life scale was detected (25). In a study conducted with 283 participants with an average age of $71.11 \pm 7.74$ years and examining the factors affecting the quality of life of the elderly living in their homes, it was found that as the functional independence of the elderly was restricted and their participation levels decreased, their quality of life decreased (2). As shown in the other studies, it was shown that the quality of life increased with the increase in community participation of elderly people living at home in our study. With the preparation of personcentered rehabilitation programs for elderly individuals living in their homes, we think that the quality of life levels can be changed positively by increasing the self-care, productivity, leisure activities and community participation levels of elderly individuals.

\section{Study Limitations}

One of the limitations of our study was that it was conducted with healthy elderly people living in Ankara, the capital city of our country, in Antalya, one of the leading cities of tourism, and in city centers. Also, the fact that the elderly living in the nursing homes were not included in our study as a separate group could be among the limitations of our study. In addition to these limitations, we think that the data obtained from the participants may yield different results in similar studies that will be performed in other cities, districts or villages.

\section{Conclusion}

Our results show that necessary interventions should be made in order to increase the quality of life of elderly people living in the home, to increase community participation which is not enough and to increase their activity performance. Necessary measures must be taken to prevent the isolation of elderly people living at home. In this context, it is very important to make plans that support healthy aging processes of geriatric individuals. However, 
we think that the data obtained from our study may contribute to geriatric rehabilitation studies that can be planned to increase the level of community participation, activity performance and quality of life of the elderly living in the home.

\section{Ethics}

Ethics Committee Approval: This study was approved by the Clinical Research Ethics Committee of Akdeniz University Faculty of Medicine (70904504/85, decision no: 178).

Informed Consent: Their written consent was obtained before the evaluation.

Peer-review: Internally and externally peer reviewed.

\section{Authorship Contributions}

Surgical and Medical Practices: H.A.T., Ö.K.K, S.Ş., Concept: H.A.T., Ö.K.K, Design: H.A.T., S.Ş., Data Collection or Processing: H.A.T., Ö.K.K, S.Ş., Analysis or Interpretation: Ö.K.K., S.Ş., Literature Search: H.A.T., Ö.K.K., Writing: H.A.T.

Conflict of Interest: No conflict of interest was declared by the authors.

Financial Disclosure: The authors declared that this study received no financial support.

\section{References}

1. Tajvar M, Arab M, Montazeri A. Determinants of health-related quality of life in elderly in Tehran, Iran. BMC Public Health 2008;8:323.

2. Altuğ F, Yağcı N, Kitiş A, Büker N, Cavlak U. Analyzing of factors affecting the quality of life in elderly at home. Yaşlı Sorunları Araştırma Dergisi 2009;1:48-60.

3. Beğer T, Yavuzer H. Yaşlılık ve Yaşlılık Epidemiyolojisi. Klinik Gelişim 2012;25:1-3.

4. Rose MR, Flatt T, Graves JL, Greer LF, Martinez DE, Matos M, et al. What is Aging? Front Genet 2012;3:134.

5. Altuntaş O, Kayıhan H. Ev Düzenlemelerinin Yaşlıların Yaşam Kalitesine Etkisi. Turk J Physiother Rehabil 2015;26:1-13.

6. Göktaş A, Pekçetin S, Tekindal B, Kayıhan H, Uyanık M. Impact of Activity Preferences on Cognitive Skills and Life Satisfaction in Elderly. Ergoterapi ve Rehabilitasyon Dergisi. 2016;4:1-14.

7. Charles ST, Carstensen LL. Social and emotional aspects of aging. Annu Rev Psychol 2010;61:383-409.

8. Ravanera ZR, Fernando R. Integration at late life inclusion, participation, and belonging among the elderly. Disabil Rehabil 2014;36:737-43.

9. Agyar E. Contribution of perceived freedom and leisure satisfaction to life satisfaction in a sample of Turkish women. Soc Indic Res 2014;116:1-15.

10. Avolio M, Montagnoli S, Marino M, Basso D, Furia G, Ricciardi W, et al. Factors influencing quality of life for disabled and nondisabled elderly population: the results of a multiple correspondence analysis. Curr Gerontol Geriatr Res 2013;1:258-74.
11. Tonak HA, Kitis A, Zencir M. Analysis of Community Participation Levels of Individuals Who Are Physically Disabled and Working in Industrial Environments. Soc Work Public Health 2016;31:638-45.

12. Gautam R, Saito T, Kai I. Leisure and religious activity participation and mental health: gender analysis of older adults in Nepal. BMC Public Health 2007;7:299.

13. Sørensen LV, Axelsen U, Avlund K. Social Participation and Functional Ability from Age 75 to Age 80. Scand J Occup Ther 2002;9:71-8.

14. Karakuş A, Süzek H, Atay ME. The Examination OfThe Depression Levels Of The Elderly Residing In Muğla Nursing Home. Sosyal ve Beşeri Bilimler Araştirmalari Dergisi 2011;11:39-51.

15. Uluğ B, Ertuğrul A, Göğüş A, Kabakçı E. Yetiyitimi Değerlendirme Çizelgesinin (WHO-DAS-II) Şizofreni Hastalarında Geçerlilik ve Güvenilirliği. Türk Psikiyatri Dergisi 2001;12:121-30.

16. Chang FH, Coster WJ, Helfrich CA. Community Participation Measures for People with Disabilities: A Systematic Review of Content From an International Classification of Functioning, Disability and Health Perspective. Arch Phys Med Rehabil 2013;94:771-81.

17. Torpil B. Multipl Skleroz'lu bireylerde Kanada Aktivite Performans Ölçümü’ nün Türkçe kültürel adaptasyonu, geçerlilik ve güvenilirliği. Ankara: Hacettepe Üniversitesi; 2017.

18. Law M, Baum C, Dunn W. Measuring Occupational Performance: Supporting Best Practice in Occupational Therapy. New Jersey: Slack Incorporated; 2005. p.440.

19. McHorney CA, Ware JE, Lu JF, Sherbourne CD. The MOS 36-item Short Form Health Survey (SF-36): III. Test of Data Quality, Scaling Assumpitons, and Reliability Across Diverse Patient Groups. Med Care 1994;32:40-66.

20. Jr Ware JE, Sherbourne CD. The MOS 36-item Short-Form Health Survey (SF-36). I. Conceptual Framework and Item Selection. Med Care 1992;30:473-83.

21. Koçyiğit H, Aydemir Ö, Fişek G, Neşe Ölmez. Kısa Form-36'nın Türkçe Versiyonunun Güvenilirliği ve Geçerliliği. İlaç ve Tedavi Dergisi 1999;12:102-6.

22. Altman D. Practical Statistics for Medical Research. London: Chapman and Hall; 1992.

23. Salar S, Günal A, Pekçetin S, Huri M, Mehr BK, Katırcıbaşı G, et al. Relationship Between Activity, Environment and Life Satisfaction in Older Adults. Ergoterapi ve Rehabilitasyon Dergisi 2016;4:89-96.

24. Raymond E, Grenier A, Hanley J. Community Participation of Older Adults with Disabilities. Journal of Community \& Applied Social Psychology 2014;24(Suppl):50-62.

25. Şahin Onat Ş, Ünsal Delialioğlu S, Özel S. The Relationship of Balance between Functional Status and Quality of Life in the Geriatric Population. Türk Fiz Tip Rehab Derg 2014;60:147-54.

26. Pino L, González-Vélez AE, Prieto-Flores ME, Ayala A, FernandezMayoralas G, Rojo-Perez F, et al. Self-perceived health and quality of life by activity status in community-dwelling older adults. Geriatr Gerontol Int 2014;14:464-73.

27. Altuntaş O, Uyanık M, Kayıhan H. Investigation of the Activities and Participation of Nursing Home Residents: A Pilot Study. Ergoterapi ve Rehabilitasyon Dergisi 2013;1:21-30. 
28. Valenti LM, Suchil C, Beltran G, Rogers RC, Massey EA, Astorino TA. Effect of Sexual Intercourse on Lower Extremity Muscle Force in Strength-Trained Men. J Sex Med 2018;15:888-93.

29. Alahmari KA, Silvian SP, Reddy RS, Kakaraparthi VN, Ahmad I, Alam MM. Hand grip strength determination for healthy males in Saudi Arabia: A study of the relationship with age, body mass index, hand length and forearm circumference using a hand-held dynamometer. J Int Medl Res 2017;45:540-8.

30. Iso-Markku P, Waller K, Kujala UM, Kaprio J. Physical activity and dementia: Long-term follow-up study of adult twins. Ann Med 2015;47:81-7.
31. Verghese J, Wang C, Katz MJ, Sanders A, Lipton RB. Leisure activities and risk of vascular cognitive impairment in older adults. J Geriatr Psychiatry Neurol 2009;22:110-8.

32. Kayıhan H, Karaduman A, Uyanık M, Düger T, Bumin G. İki Farklı İlçede Toplum Temelli Rehabilitasyonun Etkilerinin İncelenmesi. Tubitak Araştırma Projesi Proje No:107K247. Ankara; 2010.p.113.

33. Tonak HA, Kitis A. Çalışan Üst Ekstremite Problemli Özürlülerin Aktivite Düzeyi, Serbest Zaman ve Toplumsal Katılım Düzeylerinin İncelenmesi. Ergoterapi ve Rehabilitasyon Dergisi 2014;2:113-9. 